\title{
Possible Link Between Chronic Periodontal Disease and Central Nervous System Pathologies
}

\section{Posible Relación entre la Enfermedad Periodontal Crónica y Patologías del Sistema Nervioso}

Karol Gabriela Ramírez Chan DDS- Periodontist, MSc, PhD1

Affiliations:

1. Division of Biosciences, The Ohio State University College of Dentistry, Columbus, OH 43210, USA

Correspondence to: Dra. Karol Gabriela Ramírez Chan - ramirezchan.1@osu.edu

Received 8-VI-2015 Accepted 15-VI-2015

\section{ABSTRACT}

Systemic infection and/or inflammation has been related with an increased risk of brain abscesses, cerebrovascular disease, cognitive impairment and other pathological states of the brain. Therefore, it is plausible, that a chronic infection and inflammation disease, such as periodontitis, may affect the central nervous system (CNS). Chronic periodontal disease is a condition that causes breakdown of the supporting tissues of the teeth, alveolar bone and soft tissues. Chronic periodontitis is a multifactorial disease caused by dental plaque composed of pathogenic bacteria that triggers the immune response in susceptible hosts. Oral pathogenic bacteria is a source of chronic infection that can induce local and peripheral production of pro-inflammatory cytokines such as IL-1B, IL-6 and TNF- $\alpha$ inflammatory mediators, as well as bacterial products such as lipopolysaccaride endotoxin. Viruses, such as herpes and Epstein-Barr, can also be found in periodontal pockets. It is well established that oral pathogenic microorganisms may cause systemic infection by transient or persistent bacteremia, disseminating within the body, and infiltrate distal sites and organs. It has been proposed that in vulnerable populations and under certain circumstances, bacterial and viral infections may enter the brain from the bloodstream. Once in the brain, infectious pathogens and inflammatory products may compromise vascular integrity. Thus, the potential role of the pathogenesis of chronic periodontitis in the development and progression of cerebral infection and inflammation can have a link. There is no direct evidence that determines whether oral diseases have a causal association with CNS pathologies, nonetheless there are several reports that have found oral periodontal pathogens lodged in the brain. Both inflammatory states may just share a casual connection with common risk factors and complex multifactorial etiologies. However, the possibility that pathogenic oral microorganisms disseminate to the bloodstream and reach the brain, initiating or exacerbating existing cerebral lesions, cannot be disregarded. In addition, not only periodontal pathogens may be involved in invading the brain, but also, the pro-inflammatory factors induced systemically by periodontitis, may play a role in CNS pathologies. This oral systemic link will be discussed in this paper.

RAMíREZ, K., 2014: Possible Link Between Chronic Periodontal Disease and Central Nervous System Pathologies.-ODOVTOS-Int. J. Dental S.C., 16: 23-31. 


\section{KEY WORDS}

chronic periodontitis, central nervous system pathologies, infection, inflammation, periodontitis and systemic diseases, oral health, systemic health

\section{RESUMEN}

La infección y/o inflamación sistémica se ha asociado con un mayor riesgo de abscesos cerebrales, enfermedad cerebrovascular, discapacidad cognitiva, y otras patologías del sistema nervioso central (SNC). Por lo tanto, es posible que una infección crónica y enfermedad inflamatoria, como lo es la periodontitis, pueda afectar al SNC. La enfermedad periodontal crónica es una condición que causa la destrucción de los tejidos de soporte del diente, hueso y tejidos blandos. La misma, es una enfermedad multifactorial, cuya etiología es la placa dental, la cual está compuesta por bacterias que estimulan una respuesta inmune en el huésped. Los patógenos orales son una fuente de infección crónica que inducen la producción local y periférica de citocinas proinflamatorias, tales como IL-1ß, IL-6 and TNF- $\alpha$, mediadores inflamatorios, y productos bacterianos, como la endotoxina lipopolisacárida. Así mismo se pueden encontrar en bolsas periodontales virus, como el herpes y Epstein-Barr. Está establecido que patógenos orales pueden ser la causa de infecciones sistémicas por bacteremias transientes 0 persistentes, las cuales se diseminan en el cuerpo, teniendo la posibilidad de infiltrar sitios distales y órganos. También se ha propuesto, que en poblaciones vulnerables y bajo ciertas circunstancias, las infecciones bacterianas y virales pueden entrar del torrente sanguíneo al SNC. Una vez en el cerebro, los patógenos infecciosos y productos inflamatorios pueden comprometer la integridad vascular. No hay evidencia directa que determine si las enfermedades orales pueden tener asociación causal con las patologías del SNC, sin embargo, hay algunos reportes que han encontrado patógenos periodontales en tejido cerebral. Ambos estados inflamatorios pueden solamente compartir una conexión casual con factores de riesgo en común y etiologías multifactoriales complejas. Sin embargo, no se puede descartar la posibilidad que los patógenos orales se diseminen al torrente sanguíneo y que lleguen al cerebro, iniciando o exacerbando lesiones cerebrales existentes. No solamente los patógenos periodontales pueden estar involucrados en la invasión del SNC, también hay que considerar los factores inflamatorios inducidos sistémicamente por la periodontitis. Esta relación oral sistémica va a ser discutida en este artículo.

\section{PALABRAS CLAVE}

periodontitis crónica, patologías del sistema nervioso central, infección, inflamación, periodontitis y enfermedades sistémicas, salud oral, salud sistémica

\section{INTRODUCTION}

Infection and inflammation within the central nervous system (CNS) occur as consequence of systemic diseases. The only exception where a CNS infection is not acquired systemically is when bacteria are introduced to the brain by direct inoculation by neurosurgical intervention or penetrating traumas (Mueller et. al. 2009; Pachner,
2012). Among the infections that precede CNS pathologies are: peripheral sepsis, pneumonias, urinary tract infections, sinusitis, otitis, and oral infections. Bacterial and viral pathogens gain access to the brain from sites of local infection by the bloodstream and lymphatics, and cause disruption of neurological homeostasis by compromising the integrity of the blood brain barrier (BBB) and bloodcerebrospinal fluid barrier (Kang and McGavern, 2010). 


\section{PATHOGENESIS OF PERIODONTITIS}

According to the Centers for Disease Control and Prevention, the prevalence of periodontal disease in the U.S. is $45 \%$ for adults aged $45-64$ years and $58 \%$ in adults aged $65-74$ years (Eke et al. 2012). Periodontitis is a multifactorial disease that causes breakage of the supporting tissues of the tooth. If left untreated, the outcome is tooth loss. Periodontitis is caused by the accumulation of dental plaque on the tooth's surface next to supraand subgingival tissues. One periodontal pocket can contain more than 700 microorganisms. Oral pathogens are necessary to initiate periodontitis, but they are not sufficient to induce progression of disease, unless it parallels an inflammatory response, in a susceptible host. Periodontitis manifests clinically as a classical inflammatory state with infiltration of immune cells such as neutrophils, monocytes, and antibody producing plasma cells. Chronic periodontitis infection repetitively attracts leukocytes to fibrotic and granulation tissues, maintaining immune cells activated.

Two main features of periodontal disease are bone and soft tissue destruction. Release of interleukin-1B (IL-1B) by macrophages and resident fibroblasts, accompanied with increased production of prostaglandin E2 (PGE2), induce osseous resorption by osteoclasts. IL-1 and tumor necrosis factor-a (TNF- $\alpha$ ) increase the production of PGE2 by epithelial cells, monocytes and fibroblasts. These products can subsequently trigger degradative pathways such as matrix metalloproteinases (MMPS), plasminogendependent, and phagocytic polymorphonuclear serine proteinase pathways. For example, MMPS are highly expressed in gingival crevicular fluid (Armitage, 2004; Offenbacher et. al, 2010). MMPS are released in an attempt to kill bacteria; nonetheless, these enzymes end up destroying collagen fibers of the periodontal ligament and gingiva, leading to an apical migration of the junctional epithelium. Hence, pocket formation results, as the coronal portion of the gingiva separates from the root surface due to these inflammatory events.

\section{FROM THE PERIODONTAL MILIEU INTO THE BRAIN}

Subjacent to the dentogingival junction, microbial biofilms are in close proximity to a highly vascularized microenvironment. The gingival epithelium provides physical, chemical, and immunological barriers that prevent the entry of microorganisms into the circulation. If this natural barrier, which is approximately ten-cell layer thick, is breached by periodontitis, bacteremia proliferates. As periodontal vasculature permeability increases, ulcerations in the pocket lining are generated due to buildup of sub- and supragingival plaque. Thereafter, periodontal bacteria propagate to distal systems or organs, via the bloodstream or the lymphatic system, and result in inflammation of distant sites. It is worth mentioning that immunocompromised patients and elderly are more vulnerable to systemic dissemination of oral pathogens.

Invasive periodontal procedures such as root scaling and planning beyond the root apex, subgingival irrigation, dental extractions, periodontal surgery and even periodontal probing of deep pockets, elicit hematogenous seeding. Moreover, transient bacteremia is frequent during mastication and less invasive oral care procedures like tooth brushing and flossing. Using sequence analysis of 16SRNA genes, 98 different bacterial species were identified in the bloodstream of 151 bacterimic patients, following tooth brushing and exodontias (Bahrani-Mougeot et al., 2008). It has been reported that patients with severe periodontal disease can have multiple bacteremic episodes per day (Geerts et al. 2002; Forner et al. 2006). Oppositely, the number of oral pathogens reaching systemic circulation is low in patients with good oral hygiene. 
Periodontal pathogens and their products can also induce a systemic inflammatory burden. Pro-inflammatory cytokines including $\mathrm{IL}-1 \mathrm{~B}$, interleukin-6 (IL-6) and, TNF-a are released by lymphocytes and macrophages. Cytokines are degraded locally, but eventually, in repeated and high bacterial loads, cytokine receptors may become insufficient as they become saturated. Consequently, these products disseminate into systemic circulation. Elevated levels of C-reactive protein (CRP) in the blood of patients with periodontal disease have been found when compared to healthy controls (Ebersole et al, 1997; Noack et al. 2001; Pitiphat et al., 2008). Increased levels of CRP are correlated with infection of Porphyromonas Gingivalis (P. Gingivalis) and Prevetolla Intermedia, two subgingival periodontal pathogens (Noack et al., 2001).

An anatomical and functional safeguard protects the brain. Therefore, bacteria and proinflammatory mediators must colonize neural and humoral pathways in order to gain access to the CNS. There are no studies in literature describing how pathogenic oral microorganisms get in the brain, but there are numerous case reports of brain abscesses cultures testing positive for periodontal pathogens. Bacterial cultures from eleven nontraumatic brain abscesses and their respective oral infective sources for a bacterial match, revealed six cases from oral abscesses and three cases from subgingival flora (Mueller et. al., 2009). A case report and review of literature associated periodontopathogen, Aggregibacter actinomycetemcomitans (A.A.) (Rahamat-Langendoen, et al., 2011) as the cause of a brain abscess in a 42-year old patient, which had no other underlying systemic conditions. The patient presented multiple brain lesions, and initially the doctors thought of a metastatic tumor. After drainage and histopathological analysis, examiners could not detect any bacteria present in the sample. After 16S rDNA polymerase chain reaction and sequencing, A.A. was found to be the causative agent of the brain abscess. Dental examination revealed the patient had severe periodontitis. Then, after several sessions of brain abscess drainage, the patient improved, but as a result, cognitive impairment remained. This report exemplifies the value of gene amplification and sequencing as a diagnostic tool when negative cultures result in specimens of patients with chronic brain infection.

P. Gingivalis (lilda et al. 2004), and Fusobacterium nucleatum (F. nucleatum) (Ewald et al., 2006) have been associated with brain abscesses as well (Ewald et al., 2006; Uppor et al. 2012) in other case reports. F. nucleatum is a Gramnegative anaerobe subgingival pathogen, capable of inducing systemic abscesses. It has gained attention as a model microorganism to investigate the association of periodontal disease with pregnancy complications. This model can also be used to portray how F. nucleatum may cross the endothelium of the BBB. The BBB is a specialized interface of capillary endothelial cells $(E C)$ that protects the brain from peripheral blood circulation, by controlling transfer of pyrogenic elements, and at the same time, the leakage of fluids from the CNS. The BBB is one of the routes periodonto-pathogens may have to overcome to get access to the perivascular space and cause infection and inflammation.

Fusobacterium adhesin A (FadA) is a highly conserved surface adhesin in oral fusobacteria, and is not present in non-oral fusobacterium species (Han et al., 2010). FadA attaches to host's endothelial cells via vascular endothelial (VE)cadherin, a molecule that is also responsible for cell-to-cell junctions. VE-cadherin is expressed in BBB endothelial cells, as part of the tight adherence junctions that control paracellular traffic, specific transport, and extravasation of molecules. A study used affinity column chromatography and coprecipitation assays to confirm binding between $F$. nucleatum's FadA and VE-cadherin. VE-cadherin was conjugated to Gluthanione-S-Transferase (GST) and used as control GST alone. Each was 
then mixed with purified FadA and passed through gluthanione column. FadA was eluted from the column only when mixed with the fusion protein GST-VE-cadherin. Also, FadA and conjugated cytochrome c (both having similar molecular weight) were incubated with human umbilical vein endothelial cells (HUVEC), and then these were immunolabelled for VE-cadherin. Confocal microscopy showed binding of FadA to HUVEC, but not to cytochrome c (control). Additionally, the pattern distribution of VE-cadherin was disturbed when FadA was present, suggesting translocation of $\mathrm{VE}$-cadherin by FadA. F. nucleatum's binding to $\mathrm{VE}$-cadherin, and consequently invasion, was evaluated using purified FadA or VE-cadherin in HUVEC knockdown by small interfering RNA (siRNA), as well as inhibitory attachment and invasion assays. A threefold reduction was seen in the attachment of $F$. nucleautm in the silencing of $\mathrm{VE}$-cadherin. This experiment gave evidence that VE-cadherin is required for this pathogen's attachment. Furthermore, FadA was able to increase permeability of endothelial cells. FAdA was incubated with monolayers of HUVEC in transwell inserts, thus, creating a space for other pathogens to move inside. When Escherichia coli (E. coli) was incubated with F. nucleatum, it was able to cross the HUVEC monolayers, but when $\mathrm{E}$. coli was introduced alone in the transwell assays, VE-cadherin did not break and the cell layers appeared intact. (Fardini et al., 2011).

Binding of $F$. nucleatum to VE-cadherin in the $\mathrm{BBB}$ could be the first step taken by this periodontal pathogen, to invade the brain and have access to the perivascular space for colonization. F. nucleautum can further reach the parenchyma and other brain compartments, and develop a brain abscess. Another feature of $F$. nucleautm is that this microorganism is generally present in subgingival pockets coaggregated with other species. The increased permeability and weakening of endothelial junctions induced by F. nucleatum may enable coaggregated species to invade the brain causing mixed-species CNS infections. It would be interesting to characterize the interactions between FadA and VE-cadherin using brain endothelial cells to confirm this mechanism of adhesion, invasion and colonization.

P. gingivalis is able to adhere through fimbriae to EC. It has been reported that $P$. gingivalis strain W83 has cystein proteases (gingipains) that cleave VE-cadherin (Sheets et al., 2005; Sheets et. al, 2006), suggesting another virulence mechanism of invasion to EC. Activation of EC may contribute to the onset of stroke, causing reduction of oxygen in the brain that lead to other neuropathologies, such as neuronal death. Periodontopathogens such as P. gingivalis and Streptococcus Sanguis disseminate into the circulation and alter platelet function, leading to atherosclerosis and blood coagulation (Li et al. 2000). In this manner, the presence of inflammatory cytokines released into systemic circulation as a result of periodontitis, may increase platelet aggregation in blood vessels, and lead to the occlusion of cerebral arteries and veins, resulting in atherogenesis and thrombus formation.

One of the most common causes of dementia in the elderly population is Alzheimer's disease (AD) (Wallin et al., 2010). Its prevalence varies among different populations, but risk factors such as genetics and the environment, affect susceptibility to develop AD. Many of the risk factors involved in the etiology and progression of $A D$ have not been well established; nonetheless, inflammation within the CNS has been hypothesized to play a major role. It is likely that after years of systemic exposure to pro-inflammatory cytokines and mediators, these products may intensify cytokine expression in the brain, promoting neuroinflammatory signaling, atrophy of the cortex, and possibly amyloid deposition. In like manner, invasion of oral Treponemas into the brain, may directly induce an inflammatory state in the CNS. In a post-mortem study, Treponema Denticola, was detected in the cortex of fourteen of sixteen Alzheimer's brains. 
Furthermore, a greater number of Treponema species were found in specimens of $A D$ subjects than in controls (Riviere et al. 2002). Replication of this study is needed, since it is the only study in literature investigating the presence of oral Treponema species in the brain.

Gram-negative, anaerobicperiodontopathogens, rich in LPS, induce pro-inflammatory cytokines upon activation of toll-like receptor-4 (TLR-4). Also, TRL4 pathway is capable of activating macrophages and monocytes in the brain, leading to the secretion of immune end products such as nitric oxide (NO) (Cao et al., 1997; Chow et al., 1999; Verma 2006) and prostaglandins from brain EC or ependymal cells (Banks, 2010). Moreover, LPS can enhance monocyte trafficking and lymphocyte adhesion across the BBB (Persidky et al. 1997; De Vries et al. 1994). LPS rapidly activates microglia, the resident immune cells of the brain and one of the first line of defense to infectious agents in the CNS. When these cells are activated, they migrate to the sites of infection and release cytotoxic molecules to destroy potential pathogens. A study that used an agonist model of TLR-4 activation, reported that LPS (from Escherichia coli, 026:B6) induced injury to BV2 cells (immortalized mouse microglia cell line) in an analysis of cell morphology and viability assays. LPS $(1 \mu \mathrm{g} / \mathrm{ml})$ was capable of stimulating NO production, inducible nitric oxide synthase (iNOS), reactive oxygen species (ROS) generation and pro-inflammatory markers such as cyclooxygenase-2 and TNF-a. On the contrary, LPS did not increase NO or iNOS production in brain derived endothelial cells (EC). It is not clear though, if the LPS dose was not sufficient to induce the production of other inflammatory products in the latter cells. Investigators should have considered using different doses to determine if the expression of pro-inflammatory mediators is dose-dependent or not, and draw the conclusion they make that LPS was not toxic to EC directly. When EC were co-cultured with BV2 cells, it led to LPS-induced injury to EC and accumulation of
NO, and suggested that this effect was dependent on the interaction of these two cells. When EC were pretreated with NOS and ROS inhibitors, cell death was prevented. Minocycline and indomethacin protected EC from injury when cocultured with microglia and decreased production of NO. Apparently, microglial cytotoxicity induced by LPS was due to the production of NO and ROS. The researchers also elucidated that the signaling pathways involved in cytotoxicity upon TLR-4 were NF-KB, JAK-STAT, and JNK/SAPK. By inhibiting these pathways, microglial activation was reduced and cell death was prevented (Kacimi et al. 2011). Even though $E$. coli is an unusual specie in periodontal pockets, it can be found as part of the subgingival microbiota in untreated periodontitis (Colombo et al., 2002; da Silva-Boghossian et al., 2011) Despite the fact that researchers used LPS from E.coli, this model may exemplify how LPS from P. gingivalis may activate microglia and other immune cells in the brain as well, through a pattern recognition receptor. LPS from P. gingivalis is able to activate both TLR-4 and TLR-2.

Other routes of gaining access to the brain include circumventricular organs and peripheral nerves. Treponema species have been detected in trigeminal ganglion cells and the brainstem of human brains (Riviere et al. 2002). Periodontitis circumscribes the endings of the fifth cranial nerve and may explain why Spirochete species of oral origin were identified in the trigeminal ganglia and pons (Riviere et. al., 2002). Likewise, because of anatomical vicinity, periodontal pathogens might directly ascend from the oral cavity.

Besides bacteria, viruses like Herpes simplex virus (Das et al., 2012), Epstein Barr Virus, and Cytomegalovirus have been isolated from periodontal pockets (Sharma et al. 2012). Viruses remain latent in neural tissue, and entry of cytokines into the brain as a response to systemic inflammation, may reactivate these viruses and initiate or exacerbate cerebral lesions. Also, 
immunosuppression, stress, or inflammation in the brain, may trigger reactivation of latent viruses.

\section{CONCLUSIONS AND FUTURE DIRECTIONS}

Based on the contribution of periodontitis to systemic infection and inflammation, it is plausible that periodontal disease affects the CNS under certain circumstances. In the case of brain abscesses the periodonto-pathogens are likely responsible for the onset of infection, whereas in other cerebral pathologies periodontitis might not be the etiological factor, but likely to exacerbate the disease. It is possible that each disease affects the progression of the other.

Periodontal disease may promote the pool of pro-inflammatory cytokines and bacterial products in the brain. Inflammatory molecules are locally generated in the periodontal milieu due to periodontal infection and are systemically induced. As a result, periodontal infection may lead to endotoxemia and harmful pathogenic products that lead to a systemic inflammatory response. Chronic systemic infections can deteriorate vascular integrity since bacterial products are cytotoxic to the endothelium. Once these products reach the brain, they increase the BBB permeability directly or indirectly by inducing the recruitment of leukocytes. These events may be able to activate MMPs compromising the glia limitans and also primed glial cells that can reactivate existing brain pathologies.

Both periodontitis and neuropathologies share inflammation as a prominent feature. Both diseases are a result of an amplified inflammatory response in susceptible hosts. The significance of the possible link between periodontitis and neuropathologies, such as brain abscesses, stroke, and Alzheimer's disease, among others, resides in the fact that periodontitis is a preventable and treatable disease.
As of today, data to establish a bidirectional association between periodontitis and brain pathologies is unclear. Future investigations should address polymicrobial models of host cells to adequately emulate biofilm-mediated periodontitis. In vivo pathways must be identified in order to understand periodontitis-induced cerebral infections, atherogenesis, and plaque formation. Also, it has to be determined whether periodontal treatment has a beneficial role in preventing cerebral pathogenesis. Finally, with DNA profiling it is possible to match species serotypes in the brain with those in periodontal pockets and confirm if they have identical DNA homology. Genetic fingerprinting should be documented in order to establish the spread of periodonto-pathogens to CNS structures and give more evidence than the case reports available in literature.

\section{REFERENCES}

Armitage, G. C. 2004. "Analysis of Gingival Crevice Fluid and Risk of Progression of Periodontitis." Periodontology 2000 34: 109-119.

Bahrani-Mougeot, F. K., B. J. Paster, S. Coleman, J. Ashar, S. Barbuto, and P. B. Lockhart. 2008. "Diverse and Novel Oral Bacterial Species in Blood Following Dental Procedures." Journal of Clinical Microbiology 46 (6): 2129-2132.

Banks, W. A. 2010. "Blood-Brain Barrier as a Regulatory Interface." Forum of Nutrition 63: 102-110.

Cao, C., K. Matsumura, K. Yamagata, and Y. Watanabe. 1997. "Involvement of Cyclooxygenase-2 in LPS-Induced Fever and Regulation of its mRNA by LPS in the Rat Brain." The American Journal of Physiology 272 (6 Pt 2): R1712-25.

Chow, J. C., D. W. Young, D. T. Golenbock, W. J. Christ, and F. Gusovsky. 1999. "Toll-Like Receptor-4 Mediates Lipopolysaccharide-Induced Signal Transduction." The Journal of Biological Chemistry 274 (16): 10689-10692. 
Colombo, A. P., R. P. Teles, M. C. Torres, R. Souto, W. J. Rosalem, M. C. Mendes, and M. Uzeda. 2002. "Subgingival Microbiota of Brazilian Subjects with Untreated Chronic Periodontitis." Journal of Periodontology 73 (4): 360-369.

da Silva-Boghossian, C. M., R. M. do Souto, R. R. Luiz, and A. P. Colombo. 2011. "Association of Red Complex, A. Actinomycetemcomitans and Non-Oral Bacteria with Periodontal Diseases." Archives of Oral Biology 56 (9): 899-906.

Das, S., G. S. Krithiga, and S. Gopalakrishnan. 2012. "Detection of Human Herpes Viruses in Patients with Chronic and Aggressive Periodontitis and Relationship between Viruses and Clinical Parameters." Journal of Oral and Maxillofacial Pathology : JOMFP 16 (2): 203-209.

de Vries, H. E., A. C. Moor, M. C. Blom-Roosemalen, A. G. de Boer, D. D. Breimer, T. J. van Berkel, and J. Kuiper. 1994. "Lymphocyte Adhesion to Brain Capillary Endothelial Cells in Vitro." Journal of Neuroimmunology 52 (1): 1-8.

Ebersole, J. L., R. L. Machen, M. J. Steffen, and D. E. Willmann. 1997. "Systemic Acute-Phase Reactants, C-Reactive Protein and Haptoglobin, in Adult Periodontitis." Clinical and Experimental Immunology 107 (2): 347-352.

Eke, P. I., B. A. Dye, L. Wei, G. 0. ThorntonEvans, R. J. Genco, and CDC Periodontal Disease Surveillance workgroup: James Beck (University of North Carolina, Chapel Hill, USA), Gordon Douglass (Past President, American Academy of Periodontology), Roy Page (University of Washin. 2012. "Prevalence of Periodontitis in Adults in the United States: 2009 and 2010." Journal of Dental Research 91 (10): 914-920.

Ewald, C., S. Kuhn, and R. Kalff. 2006. "Pyogenic Infections of the Central Nervous System Secondary to Dental Affections--a Report of Six Cases." Neurosurgical Review 29 (2): 1636; discussion 166-7.

Fardini, Y., X. Wang, S. Temoin, S. Nithianantham, D. Lee, M. Shoham, and Y. W. Han. 2011. "Fusobacterium Nucleatum Adhesin FadA
Binds Vascular Endothelial Cadherin and Alters Endothelial Integrity." Molecular Microbiology 82 (6): 1468-1480.

Forner, L., T. Larsen, M. Kilian, and P. Holmstrup. 2006. "Incidence of Bacteremia After Chewing, Tooth Brushing and Scaling in Individuals with Periodontal Inflammation." Journal of Clinical Periodontology 33 (6): 401-407.

Geerts, S. 0., M. Nys, M. P. De, J. Charpentier, A. Albert, V. Legrand, and E. H. Rompen. 2002. "Systemic Release of Endotoxins Induced by Gentle Mastication: Association with Periodontitis Severity." Journal of Periodontology 73 (1): 73-78.

Han, Y. W., Y. Fardini, C. Chen, K. G. lacampo, V. A. Peraino, J. M. Shamonki, and R. W. Redline. 2010. "Term Stillbirth Caused by Oral Fusobacterium Nucleatum." Obstetrics and Gynecology 115 (2 Pt 2): 442-445.

lida, Y., K. Honda, T. Suzuki, S. Matsukawa, T. Kawai, T. Shimahara, and H. Chiba. 2004. "Brain Abscess in which Porphyromonas Gingivalis was Detected in Cerebrospinal Fluid." The British Journal of Oral \& Maxillofacial Surgery 42 (2): 180.

Kacimi, R., R. G. Giffard, and M. A. Yenari. 2011. "Endotoxin-Activated Microglia Injure Brain Derived Endothelial Cells Via NF-kappaB, JAK-STAT and JNK Stress Kinase Pathways." Journal of Inflammation (London, England) 8: 7-9255-8-7.

Kang, S. S. and D. B. McGavern. 2010. "Microbial Induction of Vascular Pathology in the CNS." Journal of Neuroimmune Pharmacology : The Official Journal of the Society on Neurolmmune Pharmacology 5 (3): 370-386.

Li, X., K. M. Kolltveit, L. Tronstad, and I. Olsen. 2000. "Systemic Diseases Caused by Oral Infection." Clinical Microbiology Reviews 13 (4): 547-558.

Mueller, A. A., B. Saldamli, S. Stubinger, C. Walter, U. Fluckiger, A. Merlo, K. Schwenzer-Zimmerer, H. F. Zeilhofer, and S. Zimmerer. 2009. "Oral Bacterial Cultures in Nontraumatic Brain 
Abscesses: Results of a First-Line Study." Oral Surgery, Oral Medicine, Oral Pathology, Oral Radiology, and Endodontics 107 (4): 469-476. Noack, B., R. J. Genco, M. Trevisan, S. Grossi, J. J. Zambon, and E. De Nardin. 2001. "Periodontal Infections Contribute to Elevated Systemic C-Reactive Protein Level." Journal of Periodontology 72 (9): 1221-1227.

Offenbacher, S., S. Barros, L. Mendoza, S. Mauriello, J. Preisser, K. Moss, M. de Jager, and M. Aspiras. 2010. "Changes in Gingival Crevicular Fluid Inflammatory Mediator Levels during the Induction and Resolution of Experimental Gingivitis in Humans." Journal of Clinical Periodontology 37 (4): 324-333.

Pachner, Andrew R. 2012. A Primer of Neuroimmunological Disease. New York: Springer.

Persidsky, Y., M. Stins, D. Way, M. H. Witte, M. Weinand, K. S. Kim, P. Bock, H. E. Gendelman, and M. Fiala. 1997. "A Model for Monocyte Migration through the Blood-Brain Barrier during HIV-1 Encephalitis." Journal of Immunology (Baltimore, Md.: 1950) 158 (7): 3499-3510.

Pitiphat, W., W. Savetsilp, and N. Wara-Aswapati. 2008. "C-Reactive Protein Associated with Periodontitis in a Thai Population." Journal of Clinical Periodontology 35 (2): 120-125.

Rahamat-Langendoen, J. C., M. G. van Vonderen, L. J. Engstrom, W. L. Manson, A. J. van Winkelhoff, and E. A. Mooi-Kokenberg. 2011. "Brain Abscess Associated with Aggregatibacter Actinomycetemcomitans: Case Report and Review of Literature." Journal of Clinical Periodontology 38 (8): 702-706.

Riviere, G. R., K. H. Riviere, and K. S. Smith. 2002. "Molecular and Immunological Evidence of Oral Treponema in the Human Brain and their
Association with Alzheimer's Disease." Oral Microbiology and Immunology 17 (2): 113-118. Sharma, R., 0. Padmalatha, G. Kaarthikeyan, N. D. Jayakumar, S. Varghese, and K. Sherif. 2012. "Comparative Analysis of Presence of Cytomegalovirus (CMV) and Epsteinbarr Virus -1 (EBV-1) in Cases of Chronic Periodontitis and Aggressive Periodontitis with Controls." Indian Journal of Dental Research : Official Publication of Indian Society for Dental Research 23 (4): 454-458.

Sheets, S. M., J. Potempa, J. Travis, C. A. Casiano, and H. M. Fletcher. 2005. "Gingipains from Porphyromonas Gingivalis W83 Induce Cell Adhesion Molecule Cleavage and Apoptosis in Endothelial Cells." Infection and Immunity 73 (3): 1543-1552.

Sheets, S. M., J. Potempa, J. Travis, H. M. Fletcher, and C. A. Casiano. 2006. "Gingipains from Porphyromonas Gingivalis W83 Synergistically Disrupt Endothelial Cell Adhesion and can Induce Caspase-Independent Apoptosis." Infection and Immunity 74 (10): 5667-5678.

Socransky, S. S. and A. D. Haffajee. 2002. "Dental Biofilms: Difficult Therapeutic Targets." Periodontology 2000 28: 12-55.

Uppoor, A. S., H. S. Lohi, and D. Nayak. 2012. "Periodontitis and Alzheimer's Disease: Oral Systemic Link Still on the Rise?" Gerodontology. Verma, S., R. Nakaoke, S. Dohgu, and W. A. Banks. 2006. "Release of Cytokines by Brain Endothelial Cells: A Polarized Response to Lipopolysaccharide." Brain, Behavior, and Immunity 20 (5): 449-455.

Wallin, A. K., K. Blennow, H. Zetterberg, E. Londos, L. Minthon, and O. Hansson. 2010. "CSF Biomarkers Predict a More Malignant Outcome in Alzheimer Disease." Neurology 74 (19): 1531-1537. 